\title{
The use of geographic information systems for the optimal location of biomass power plants in the Madrid community (Spain)
}

Article in Applied engineering in agriculture · June 2015

Impact Factor: 0.41 · DOI: 10.13031/aea.31.10984

READS

26

4 authors, including:

Luis Romero

National Distance Education University

30 PUBLICATIONS 9 CITATIONS

SEE PROFILE

Maria Luisa Cuadrado

Universidad Politécnica de Madrid

15 PUBLICATIONS 77 CITATIONS

SEE PROFILE
María Romero

National Distance Education University

18 PUBLICATIONS 8 CITATIONS

SEE PROFILE 


\title{
THE USE OF GEOGRAPHIC INFORMATION SYSTEMS FOR THE OPTIMAL LOCATION OF BIOMASS POWER PLANTS IN THE MADRID COMMUNITY (SPAIN)
}

\author{
L. Romero, M. Romero, M. L. Cuadrado, J. Fernández
}

\begin{abstract}
This article has been extracted from the results of a thesis entitled "Potential bioelectricity production of the Madrid Community Agricultural Regions based on rye and triticale biomass." The aim was, first, to quantify the potential of rye (Secale Cereale L.) and triticale (Triticosecale Aestivum L.) biomass in each of the Madrid Community agricultural regions, and second, to locate the most suitable areas for the installation of power plants using biomass.

At least 17,339.9 t d.m. of rye and triticale would be required to satisfy the biomass needs of a $2.2 \mathrm{MW}$ power plant, (considering an efficiency of 21.5\%, 8,000 expected operating hours/year and a biomass LCP of 4,060 kcal/kg for both crops), and 2,577 ha would be used (which represent 2.79\% of the Madrid Community fallow dry land surface).

Biomass yields that could be achieved in Madrid Community using 50\% of the fallow dry land surface (46,150 ha representing 5.75\% of the Community area), based on rye and triticale crops, are estimated at 84,855, 74,906, 70,109, 50,791, 13,481, and 943 t annually for the Campiña, Vegas, Sur Occidental, Area Metropolitana, Lozoya-Somosierra, and Guadarrama regions. The latter represents a bioelectricity potential of 10.77, 9.5, 8.9, 6.44, 1.71, and $0.12 \mathrm{MW}$, respectively.
\end{abstract}

Keywords. Bioelectricity, GIS, Multiple regression, Simulation model, Energy crops.

$\mathrm{T}$ The fight against climate change is a political priority in the environmental arena, both for the European Union and Spain (IDAE, 2011). In this context, the use of renewable energy is a key part of the proposal "packages" necessary for reducing greenhouse emissions and complying with the Kyoto Protocol and other international commitments.

The development of renewable energy from biomass, with the support of the various administrations, is expanding and is feasible from a technical and economic point of view. More specifically, in the Madrid Community, there is a great potential of biomass related to the available agricultural area, mostly in the southern regions.

Submitted for review in September 2014 as manuscript number 10984; approved for publication by the Applied Science \& Engineering Community of ASABE in March 2015.

The authors are Luis Romero, Assistant Professor, Dept. de Ingeniería de Construcción y Fabricación, Escuela Técnica Superior de Ingenieros Industriales, Univ. Nacional de Educación a Distancia (UNED); María Romero, Professor, Dept. de Organización de Empresas, Facultad de Ciencias Económicas y Empresariales, Univ. Nacional de Educación a Distancia (UNED), Madrid, Spain; María Luisa Cuadrado, Professor, Dept. de Matemática Aplicada a las Tecnologías de la Información, Escuela Técnica Superior de Ingenieros de Telecomunicación, Univ. Politécnica de Madrid (UPM), Madrid, Spain. and Jesús Fernández, Professor, Dept. de Producción Vegetal: Botánica y Protección Vegetal, Escuela Técnica Superior de Ingenieros Agrónomos, Univ. Politécnica de Madrid (UPM), Madrid, Spain. Corresponding author: Luis Romero, Dept. de Ingeniería de Construcción y Fabricación, Escuela Técnica Superior de Ingenieros Industriales, Universidad Nacional de Educación a Distancia (UNED), Madrid, Spain; phone: +34 91 3989621; e-mail: 1romero@ind.uned.es.
There is currently no study in Madrid estimating its biomass potential for bioelectricity production based on energy crops. By assessing that potential in the various agricultural regions of the Madrid Community based on rye and triticale crops, we have analyzed the most convenient locations for installing possible bioelectricity plants. As described by Fernández (2001), a bio-electrical system consists of the following components: raw material (biomass), a processing plant, and an electricity distribution system.

Although there is a wide range of possibilities for new biomass crops, given the tradition of those crops in Spain, cereals are the ones most suitable for obtaining biomass for heat or electricity production. Cereal biomass, in general, and rye and triticale biomass, in particular, has been used over the years for this purpose, by developing varieties that have been genetically selected in order to achieve high yields with some crops that have already shown a good resistance to drought and low temperatures (IDAE, 2007). It is necessary to specify that the cereals are not used as grain but as comprehensive biomass harvested at the time of the "dough stage," which is a lignocellulosic type of biomass.

In this work, we explore the potential biomass production of rye and triticale in the Madrid Community (based on yield simulation models) and their potential use for electricity production in each of the six agricultural regions of that Community using Geographic Information Systems (GIS).

The most complex crops simulation models allow for a sensitivity analysis of performance based on several factors, combining different types of soil, climate, and crop 
management. Most applications of the models are related to management issues, such as fertilization or irrigation strategies, planting dates or different crop cycles, which should be evaluated according to a time series of climate data (Rocha et al., 2012). In particular, regression models are considered as being a good tool for predicting the crops' potential productivity for implementing those unproductive or absent crop lands.

In Spain, the data collected by the "Proyecto Singular y Estratégico (PSE) On Cultivos" (CIEMAT, 2011), provide a valuable insight into the development, demonstration and evaluation of the feasibility of energy production from biomass energy crops in Spain. A demonstration program of annual grasses for biomass was also performed and a series of tests on different varieties of triticale, rye, oats and sorghum were carried out at different points of the Spanish geography during the 2009-2010 and 2010-2011 agricultural seasons. Data from these trials range from $1,960 \mathrm{~kg} / \mathrm{ha}$, obtained with the Carotop variety in the town of Villarrobledo (Albacete) by GA-UPM in the 2009-2010 season, and $17,331 \mathrm{~kg} / \mathrm{ha}$, obtained with the Plácido variety in the town of San Llorente by ITACYL in the same year. Triticale ranged from $1,863 \mathrm{~kg} / \mathrm{ha}$, obtained with the Amarillo variety in the town of Castelnou (Teruel) by CIRCE/UZ in the 2009-2010 season, and 18,100 kg/ha, obtained with the Titania variety in the town of La Tallada d'Empordá (Girona) by IRTA in the same period.

Furthermore, Geographic Information Systems (GIS), a tool for digitally processing cartographic data, determine if a particular location is suitable for a special purpose, establishing temporary differences with a given location and performing statistical distributions for analysis and modeling land use decision-making processes, as described by Álvarez (2004).

Many studies have been conducted in Spain and Europe on the application of GIS in various fields of biomass such as in transport logistics and storage of biomass, waste location, and pruning ratios of herbaceous and woody crops, development of biomass production models of different crops or bioelectric plant location (Voivontas et al., 2001; Beccali et al., 2009; Lovett et al., 2009; Fiorese and Guariso, 2010; Fernandes and Costa, 2010), but perhaps the most suitable one for the specific objectives of this work was developed by Perpiñá et al. (2009), who applied a methodology based on the strategies in logistics and transport that can be used to locate a network of bioenergy plants in the Valencia Community.

\section{MATERIAL AND MethodS}

The objective of this work was to evaluate the potential biomass production of rye (Secale Cereale L.) and triticale (Triticosecale Aestivum L.) in the Madrid Community, and the possibility of its use for the production of electrical energy in each of the six agricultural regions.

Although lignocellulosic biomass can be used for various purposes, such as electricity production, heat production, co-generation, co-firing, biofuels or biogas production, this article only examines the first option.
The work methodology has been designed according to the following phases of development:

1. To determine the potentially usable area for crops.

2. To generate a biomass crops production model and to quantify the potential production of available rye and triticale biomass.

3. To perform a GIS analysis for the determination of the most suitable location for a bioelectricity plant in each of the regions.

\section{Available Surface}

To assess the agricultural surface that could potentially be devoted to rye and triticale cultivation for biomass production in each of the study agricultural regions, we established a scenario that represents a percentage of fallow dry land surface.

\section{Biomass Production Model of Rye and TRiticale}

The assessment of potential biomass production of rye and triticale in available agricultural areas of each municipality was made through models or production functions that correlate the climate variables and known production of representative cereal crops in each area with the expected productivity.

For the development of these models, regression and multiple correlation techniques which quantify the statistical association between two or more variables were used.

To develop the biomass production model, both in the case of rye and triticale, a grain yield model based on tests or inspections carried out in the Madrid Community was first generated, and subsequently the biomass/grain ratio of each one of the species was calculated on the basis of a pilot project carried out in the Escuela Técnica Superior de Ingenieros Agrónomos (E.T.S.I.A.) practice fields, Madrid.

\section{Grain Production Model}

For the elaboration of this model, a relationship between average grain production trials data and weather variables [average temperature and total precipitation of the period collected from the "Agencia Estatal de Meteorología (AEMET)"] measured in the area of each of these tests was established. Temperature and precipitation data taken between October and June from the corresponding weather stations with available data nearest to the sampled rye and triticale grain yield trials were also used.

Only climatological variables were used because both crops have a small root system and fallow dry lands are considered to be suitable for cereal cultivation.

Trial values of rye and triticale grain production used were collected in the "Encuesta sobre Superficies y Rendimientos" (ESYRCE) of MAGRAMA during the 20082009, 2009-2010, 2010-2011, and 2011-2012 seasons.

For the particular case of this work, multiple regression logarithmic curves were incorporated into the model in order to control the production and ensure that it did not trigger extreme climate values. It is estimated that equations have a good correlation when the determination index $\left(\mathrm{R}^{2}\right)$ is situated between 0.8 and 1 (Montgomery et al., 2012). The tool used for obtaining this regression was Microsoft Excel 2010 (Redmond, Wash.). 
First, it was necessary to normalize the climatological data in order to be able to introduce dimensionless values into the model. The basis for the temperature normalization took the value of 9.9 , and 496.7 for the rainfall i.e. values corresponding to the municipality average in the Madrid Community for a series of 30 years (1971-2000) between June and October provided by the AEMET.

Average values of the gauging grouped per seasons and weather stations were used. For the data entry in the model, rainfall influenced the temperature twice.

\section{Biomass/Grain Ratio Obtainment}

At the experimental stage, four varieties of rye and triticale were chosen. In the case of rye they were: Petkus, Carotop, Agronom, and Fugato; and for triticale varieties: Amarillo, Trujillo, Collegial, and Bienvenu.

The study aimed to obtain the total biomass/grain ratio of different rye and triticale varieties, subjected to two different rainfall regimes. To do so, 48 containers were stacked, 24 for each irrigation type, and within each irrigation group, 3 replications for each variety in turn were made.

The experiment was performed in $40 \times 60 \times 40 \mathrm{~cm}$ containers (so the surface was $0.252 \mathrm{~m}^{2}$ ), filled with a lowfertility soil in order to enhance the effect of the fertilization. The soil characteristics were the following: sandy texture $(77.6 \%$ sand, $6.4 \%$ silt, $16 \%$ clay $), \mathrm{pH}(1: 2.5$ $\mathrm{H}_{2} \mathrm{O}$ ) 8.2, organic matter $0.32 \%$, nitrogen $0.11 \% \mathrm{~N}$, phosphorous (Olsen) $19 \mathrm{ppm} \mathrm{P}$, potassium $\left(1 \mathrm{~mol} \mathrm{\textrm {L } ^ { - 1 }}\right.$ ammonium acetate) $148 \mathrm{ppm} \mathrm{K}$, chlorine (2:10 soil/water) 135 ppm Cl (Solano et al., 2010).

Planting date of all varieties was 20 November 2009, and the planting dose applied was:

- Triticale varieties: $5.54 \mathrm{~g} /$ container.

- Petkus and Carotop Rye: $5.04 \mathrm{~g} /$ container.

- Agronom and Fugato Rye: 2.02 g/container.

Fund and cover fertilization dates were 20 November 2009 and 26 March 2010, respectively. Applied amounts were:

- Fund fertilization (NPK, 15-15 - 15): $6.3 \mathrm{~g} /$ container.

- Cover fertilization (Urea): $3.02 \mathrm{~g} /$ container.

The planting dose, which mainly varies due to seed size, is specified by distributors of each of the varieties. Since all the containers were placed under a plastic cover, irrigation was performed through contribution. To define the monthly distribution of the water supply in the two irrigation types, from the SIGA application, two different rainfall models were used to simulate the natural rainfall distribution. The first one was at Ciudad Universitaria in Madrid (419.4 mm/year), because this area is the trial location, and the other was Alar del Rey (Palencia), chosen in this case due to its $600 \mathrm{~mm}$ annual rainfall. In this way, irrigation simulated rainfall throughout the growing cycle.

The rainfall of each month was distributed evenly in two or three irrigations during each of the months, first from planting until the first harvest, and then up to the second harvest.

With two of the three replicates of each variety for each irrigation type, a first harvest was performed when it was observed that the maturation state was the so-called pasty or doughy maturity. In this case, a first weight of fresh biomass was recorded (as soon as it was cut), and, after 2-3 days in an oven, the dry matter was again weighed.

The objective of the first harvest, on 19 and 20 May 2010 , was to identify the biomass production in fresh and dry doughy grain state. A $15 \%$ biomass loss was considered in the process.

At the end of the grain drying period, the remaining replicates of each variety for each irrigation type were harvested. In this case, straw, spike, and grain were weighed separately. The second harvest, on 16 and 17 June 2010, aimed to determine the grain production and relate the final weight of the grain to the dry biomass harvested in the mature doughy grain period (biomass/grain ratio) for each of the varieties.

\section{Potential Production Based on the Developed Models}

The biomass potential, based on rye and triticale crops at a municipal level in the Madrid Community, can be quantified from the potentially usable area and rye and triticale biomass production models.

To calculate the biomass potential in each of the agricultural regions of the Madrid Community, possible rye or triticale cultivation was chosen in each municipality area depending on which of the two provided a higher biomass yield, based on already developed models.

\section{GIS ANALYSIS FOR AGRO-INDUSTRY LOCALIZATION}

The optimal location of a small biomass plant (2.2 MW) can be determined in each of the six Madrid Community agricultural regions, provided that there is enough biomass potential. Furthermore, the maximum bioelectricity potential in each of the cases can subsequently be estimated.

The choice of a $2.2 \mathrm{MW}$ installed power plant is due in accordance with the "Real Decreto 661/2007", of 25 May, which establishes a fee per $\mathrm{kWh}$ produced. The fee is higher for the plants with a power equal to, or less than, $2 \mathrm{MW}$; power that is exaggerated/increased by $10 \%$ to take into account the net production decrease due to auxiliary loads. However, with the latest modifications in the pricing of electricity production in the Special Regime, the differences in the installation cannot be conclusively estimated.

Geographic Information Systems (GPS) were employed to identify the ideal location of the power plants and the process consisted of two phases:

1. Diagnosis of suitable areas in the Madrid Community for biomass power plants location based on a series of pre-established criteria (Hidalgo, 2003; Martínez, 2009):

a) Existence of a substation in a radius of less than $10 \mathrm{~km}$.

b) Impossibility to locate in a radius of less than $2 \mathrm{~km}$ around the different municipalities.

c) Impossibility to locate in a radius of less than $2 \mathrm{~km}$ around the protected natural spaces in the Madrid Community.

d) The distance from the power plant to river courses should be in the range of 1 to $5 \mathrm{~km}$. 
The distance from the plant to the road network can not exceed $1.5 \mathrm{~km}$.

2. Determination of the municipality area within each agricultural region around which a minimum action radius is needed to obtain the total biomass necessary for supplying a $2.2 \mathrm{MW}$ plant based on the most favorable crop per municipality. The potentially usable biomass of the municipalities whose centroids are included within the action radius was taken into account as storage centers adjacent to the towns, from which biomass could be transported more expediently, were available.

The required surface for the installation of a $2.2 \mathrm{MW}$ bioelectricity plant and for the biomass storage area is approximately half a hectare, so in principle there should be no problem in finding an appropriate plot within the designated areas.

According to the Natural Electric S.A. Company (Madrid, Spain), using a natural circulation boiler tube-with a mobile grille of alternative movement, a working pressure in the boiler of 42 bars, and a maximum continuous steam production of $11,000 \mathrm{~kg} / \mathrm{h}$ - and a twin turbine running with a double radial stage and an axial stage and, finally, an electric generator of $2.630 \mathrm{kVA}, 6.6 \mathrm{kV}$, and IP 44R, the expected performance could be $8,000 \mathrm{~h} /$ year with an efficiency that varies between $21 \%$ and $22 \%$.

\section{RESULTS}

\section{Potentially Usable Surface}

Fifty percent of fallow dry land surface in each of the Madrid Community municipalities is allocated for rye and triticale cultivation.

For the drafting of this section, the fallow dry land surfaces data with respect to the year 2011 provided by the "Subdirección General de Política Agraria y Desarrollo Rural" of the Madrid Community was employed. The total of these areas grouped by agricultural regions are shown in table 1 .

\section{BIOMASS Production MOdels FOR RYE AND Triticale}

We generated a model which results from the combination of biomass-grain ratio and the model that establishes the grain production based on climatological data.

\section{Grain Production Model}

This model correlates precipitation and temperature data with known values of rye and triticale grain production trials.

Table 1. The total surface and that corresponding to fallow dry land according to the considered scenario (E)

for each of the Madrid Community.

\begin{tabular}{lcc}
\hline \multicolumn{1}{c}{ Region } & Mun Suf (ha) & Falow Surface (ha) \\
\hline Área Metropolitana & 173,893 & 7,979 \\
Campiña & 108,013 & 13,407 \\
Guadarrama & 96,639 & 127 \\
Lozoya Somosierra & 153,339 & 1,798 \\
Sur Occidental & 139,493 & 10,803 \\
Vegas & 130,803 & 12,036 \\
\hline Total & 802,180 & 46,150 \\
\hline
\end{tabular}

For its elaboration, as mentioned above, average values of rye and triticale grain production trials, collected by the "Encuesta sobre Superficies y Rendimientos" (ESYRCE) of MAGRAMA during 2008-2009, 2009-2010, 2010-2011 and 2011-2012 seasons, were used, while the climatological data of precipitation and temperature from different weather stations located in the Madrid Community were provided by the "Agencia Estatal de Meteorología" (AEMET).

Tables 2 and 3 specify the estimated grain yield in $\mathrm{kg} / \mathrm{ha}$, the weather stations nearest to them, and the variables of rainfall and temperature from October to June in each of the seasons considered.

As mentioned earlier, logarithmic regression curves were used to obtain these models, and the equations were valid if the determination index $\left(\mathrm{R}^{2}\right)$, which shows the data variability percentage, is over 0.8 in each of the cases.

After carefully analyzing the rye grain production data with respect to their normalized climate variables, the following model of rye grain production in tons per hectare is obtained (where $\mathrm{TN}=$ standardized average temperature and $\mathrm{PN}=$ normalized cumulative precipitation):

$$
\begin{gathered}
\text { Rye grain production }(\mathrm{t} / \mathrm{ha})= \\
1.078 * \ln (\mathrm{TN}+2 * \mathrm{PN})+2.3256
\end{gathered}
$$

The determination index $\left(\mathrm{R}^{2}\right)$ for the rye grain production model was 0.9234 , so that the desired characteristics were met.

Further, after analyzing the triticale grain production data with respect to their normalized climate variables, the triticale grain production model in tons per hectare was obtained (where $\mathrm{TN}=$ standardized average temperature and $\mathrm{PN}=$ normalized cumulative precipitation):

\begin{tabular}{|c|c|c|c|c|}
\hline Season $^{[b]}$ & $\begin{array}{c}\text { Avg. Yield } \\
(\mathrm{kg} / \mathrm{ha})\end{array}$ & Weather Station & $\begin{array}{l}\mathrm{T}^{\mathrm{a}[\mathrm{c}]} \\
\left({ }^{\circ} \mathrm{C}\right)\end{array}$ & $\begin{array}{c}\mathrm{P}^{[\mathrm{d}]} \\
(\mathrm{mm})\end{array}$ \\
\hline $2008-09$ & 1,987 & Madrid/Getafe & 12.4 & 263.8 \\
\hline $2009-10$ & 2,291 & Villamanrique Tajo (Bodegones) & 11.4 & 455.3 \\
\hline 2010-11 & 2,111 & Villamanrique Tajo (Bodegones) & 11.1 & 311.1 \\
\hline 2010-11 & 2,206 & Madrid/Getafe & 12.6 & 337.6 \\
\hline $2010-11$ & 2,217 & Villaviciosa De Odon & 11.4 & 402 \\
\hline $2010-11$ & 2,250 & Fuente El Saz & 11.6 & 423.9 \\
\hline 2010-11 & 2,390 & Talamanca Del Jarama & 11.9 & 454.7 \\
\hline $2011-12$ & 2,000 & Fuente El Saz & 11.5 & 252.8 \\
\hline \multicolumn{5}{|c|}{ [a] Source: MAGRAMA/AEMET. } \\
\hline [b] Octobe & to June. & & & \\
\hline Averas & temperatur & & & \\
\hline
\end{tabular}

Table 2. Rye trials carried out in the Madrid Community. ${ }^{|a|}$

Table 3. Triticale trials carried out in the Madrid Community. ${ }^{[a]}$

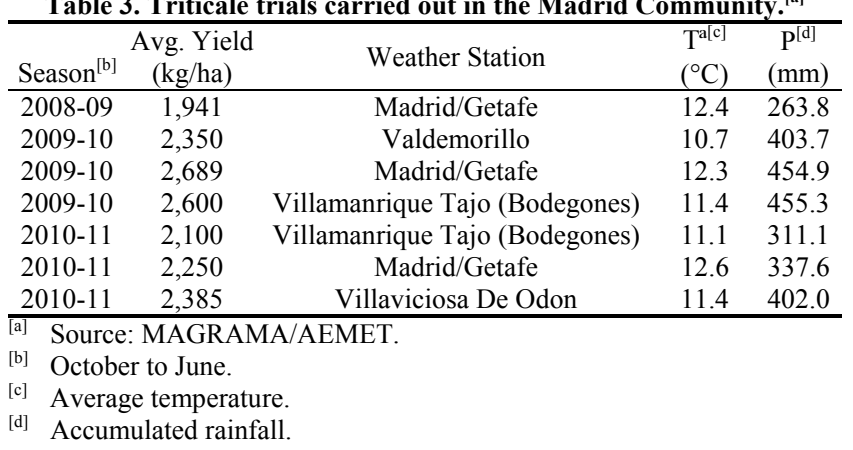


Triticale grain production $(\mathrm{t} / \mathrm{ha})=$

$$
2.4495 * \ln (\mathrm{TN}+2 * \mathrm{PN})+2.6103
$$

The determination index $\left(\mathrm{R}^{2}\right)$ for the triticale grain production model was 0.9804 , so again the desired characteristics were met.

The normalized average of a 30-year meteorological series (1971-2000) facilitated by the AEMET has been used for the calculation of rye and triticale production grain at a municipality level.

\section{Biomass/Grain Ratio}

For the calculation of the biomass production of rye and triticale varieties, two out of three replicates of each variety were used for each irrigation type. This harvest was made with doughy maturity grain.

A second harvest at the end of the grain drying period was made with the third replication of each variety of rye and triticale for each irrigation type. The objective of this second harvest was to determine the grain production and the biomass/grain ratio of each of the varieties.

The results for each irrigation type are indicated in tables 4 and 5 for rye, and in tables 6 and 7 in the case of triticale.

The biomass/grain average ratio in the case of rye is 2.785. According to the tests conducted by the Agroenergy group of UPM in the Madrid Community, in the municipalities of Quijorna and Daganzo de Arriba and in the E.T.S.I.A. practice fields during the 2009-2010 and 2010-2011 seasons, collected by PSE OnCultivos (CIEMAT, 2011), the biomass/grain average ratio for rye varieties was 2.678 , so the value obtained in the experiment, despite being executed during a single season, is considered as being acceptable for the rye biomass production model.

The biomass/grain average ratio in the case of triticale is 2.595. According to the tests conducted by the Agroenergy group of UPM in the Madrid Community, in the municipalities of Quijorna and Daganzo de Arriba, and in the E.T.S.I.A. practice fields during the 2009-2010 and 2010-2011 seasons, collected by PSE OnCultivos

Table 4. Grain and dry biomass average productions and biomass/grain ratio of each rye variety for the irrigation of $348.8 \mathrm{~mm} /$ season.

\begin{tabular}{lccc}
\hline Variety & $\begin{array}{c}\text { Total Grain } \\
\left(\mathrm{g} / \mathrm{m}^{2}\right)\end{array}$ & $\begin{array}{c}\text { Dry Biomass } \\
\left(\mathrm{g} / \mathrm{m}^{2}\right)\end{array}$ & $\begin{array}{c}\text { Biomass/Grain } \\
\text { Ratio }\end{array}$ \\
\hline Petkus & 234.16 & 557.30 & 2.38 \\
Carotop & 189.80 & 430.85 & 2.27 \\
Fugato & 181.72 & 470.65 & 2.59 \\
Agronom & 140.30 & 419.50 & 2.99 \\
\hline Average & 186.50 & 469.58 & 2.52 \\
\hline
\end{tabular}

\begin{tabular}{lccc} 
& $\begin{array}{c}\text { Table 5. Grain and dry biomass average productions } \\
\text { and biomass/grain ratio of each rye variety } \\
\text { for the irrigation of } \mathbf{4 6 2 . 1} \mathbf{~ m m} / \text { season. }\end{array}$ \\
\hline Variety & $\begin{array}{c}\text { Total Grain } \\
\left(\mathrm{g} / \mathrm{m}^{2}\right)\end{array}$ & $\begin{array}{c}\text { Dry Biomass } \\
\left(\mathrm{g} / \mathrm{m}^{2}\right)\end{array}$ & $\begin{array}{c}\text { Biomass/Grain } \\
\text { Ratio }\end{array}$ \\
\hline Petkus & 224.69 & 786.40 & 3.50 \\
Carotop & 259.54 & 643.65 & 2.48 \\
Fugato & 184.38 & 564.20 & 3.06 \\
Agronom & 194.45 & 637.80 & 3.28 \\
\hline Average & 215.76 & 658.01 & 3.05 \\
\hline
\end{tabular}

Table 6. Grain and dry biomass average productions and biomass/grain ratio of each triticale variety for the irrigation of $348.8 \mathrm{~mm} / \mathrm{season}$.

\begin{tabular}{lccc}
\hline \multicolumn{4}{c}{ irrigation of $\mathbf{3 4 8 . 8} \mathbf{~ m m} / \mathbf{s e a s o n}}$. \\
\hline Variety & $\begin{array}{c}\text { Total Grain } \\
\left(\mathrm{g} / \mathrm{m}^{2}\right)\end{array}$ & $\begin{array}{c}\text { Dry Biomass } \\
\left(\mathrm{g} / \mathrm{m}^{2}\right)\end{array}$ & $\begin{array}{c}\text { Biomass/Grain } \\
\text { Ratio }\end{array}$ \\
\hline Amarillo & 232.88 & 510.00 & 2.19 \\
Trujillo & 197.07 & 500.55 & 2.54 \\
Colegial & 140.10 & 361.45 & 2.58 \\
Bienvenu & 267.94 & 533.20 & 1.99 \\
\hline Average & 209.50 & 476.30 & 2.27 \\
\hline
\end{tabular}

Table 7. Grain and dry biomass average productions and biomass/grain ratio of each triticale variety for the irrigation of $\mathbf{4 6 2 . 1} \mathbf{~ m m} /$ season.

\begin{tabular}{lccc}
\hline Variety & $\begin{array}{c}\text { Total Grain } \\
\left(\mathrm{g} / \mathrm{m}^{2}\right)\end{array}$ & $\begin{array}{c}\text { Dry Biomass } \\
\left(\mathrm{g} / \mathrm{m}^{2}\right)\end{array}$ & $\begin{array}{c}\text { Biomass/Grain } \\
\text { Ratio }\end{array}$ \\
\hline Amarillo & 230.08 & 756.95 & 3.29 \\
Trujillo & 266.31 & 774.95 & 2.91 \\
Colegial & 153.83 & 481.50 & 3.13 \\
Bienvenu & 330.37 & 842.45 & 2.55 \\
\hline Average & 245.15 & 713.96 & 2.91 \\
\hline
\end{tabular}

(CIEMAT, 2011), the biomass/grain average ratio for triticale varieties was 2.633 , so the value obtained in the experiment, despite being executed during a single season, is also considered to be acceptable for the triticale biomass production model.

\section{Biomass Production Model}

By associating biomass-grain average ratios obtained in the experiment with grain production models, biomass production models in tons of rye and triticale per hectare were determined (where $\mathrm{TN}=$ normalized average temperature and $\mathrm{PN}=$ normalized cumulative precipitation):

$$
\begin{gathered}
\text { Rye biomass production }(\mathrm{t} / \mathrm{ha})= \\
2.785 *[1.078 * \ln (\mathrm{TN}+2 * \mathrm{PN})+2.3256] \\
\text { Triticale biomass production }(\mathrm{t} / \mathrm{ha})= \\
2.595 *[2.4495 * \ln (\mathrm{TN}+2 * \mathrm{PN})+2.6103]
\end{gathered}
$$

Table 8 presents, at a regional level, the estimated average productivity of rye and triticale biomass based on the developed models.

For the calculations of biomass potential in each of the Madrid Community agricultural regions, the crop which obtained the highest yield was considered in each of the municipality's areas. According to the data obtained by GIS, shown in figure 1, approximately $48 \%$ of the

\begin{tabular}{|c|c|c|}
\hline & $\begin{array}{l}\text { Rye Biomass Prod. } \\
\text { (tons/ha) }\end{array}$ & $\begin{array}{l}\text { Triticale Biomass Prod. } \\
\text { (tons/ha) }\end{array}$ \\
\hline Region & $\begin{array}{c}\mathrm{Y}=2.785 * \\
{[1.078 * \ln (\mathrm{TN}+2 \mathrm{PN})} \\
-2.3256]\end{array}$ & $\begin{array}{c}\mathrm{Y}=2.595 * \\
{[2.4495 * \ln (\mathrm{TN}+2 \mathrm{PN})} \\
+2.6103]\end{array}$ \\
\hline Área Metropolitana & 6.40 & 6.20 \\
\hline Campiña & 6.33 & 6.04 \\
\hline Guadarrama & 7.22 & 7.87 \\
\hline Lozoya Somosierra & 6.97 & 7.36 \\
\hline Sur Occidental & 6.60 & 6.61 \\
\hline Vegas & 6.26 & 5.89 \\
\hline
\end{tabular}
municipalities are suitable for triticale cultivation and the remaining $52 \%$ for rye cultivation.

Table 8. Average production of rye and triticale biomass in each agricultural region based on the biomass production models. 


\section{RYE AND TRITICALE CROPS DISTRIBUTION BY MUNICIPALITIES}

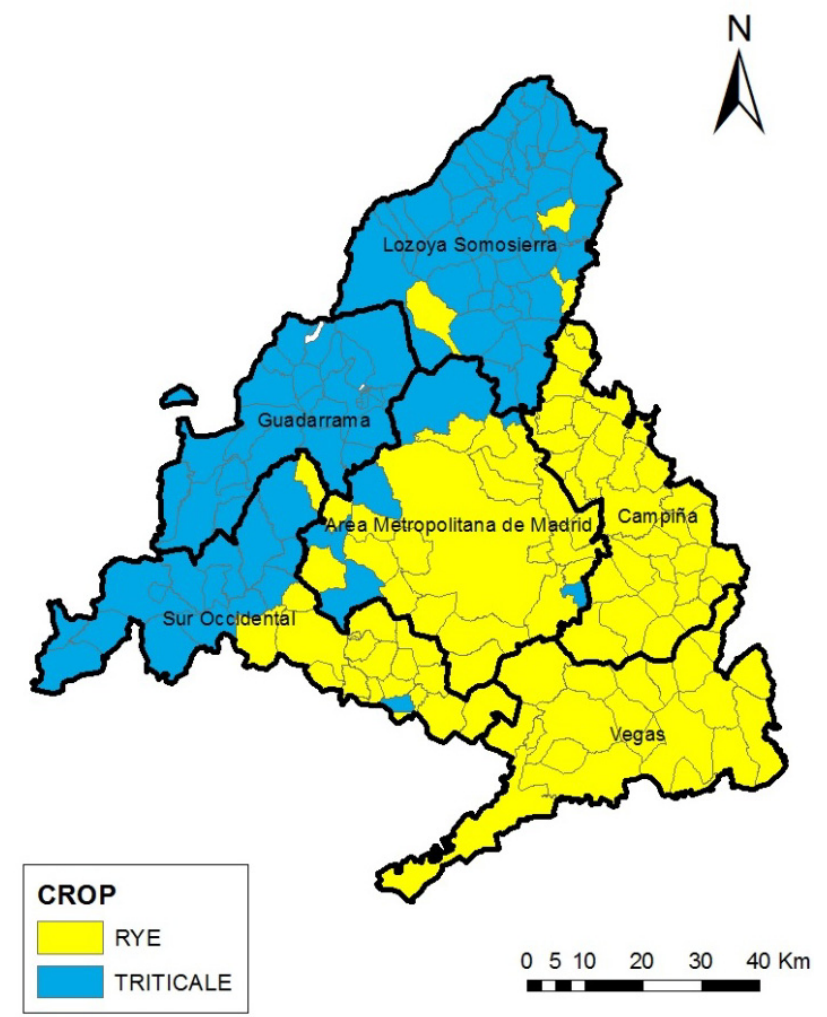

Figure 1. Distribution of rye and triticale crops in the different municipalities of the Madrid Community.

Estimated average production of rye and triticale biomass in the Madrid Community based on developed models is 6.58 and $6.88 \mathrm{t} \mathrm{d.m./ha,} \mathrm{respectively.} \mathrm{These}$ values are considered to be intermediate ones compared to the values collected in the trials carried out in this region.

\section{Potential Biomass Production in the Madrid Community Based on Rye and Triticale Crops}

The biomass potential at a municipality level in the Madrid Community has been quantified based on the rye and triticale biomass production models discussed in the previous section. Collection of potentially usable biomass would be performed at storage centers adjacent to the towns of each municipality, which would facilitate its transportation logistics.

Table 9 shows the potential production grouped by agricultural regions, based on the developed models.

\begin{tabular}{lc}
\multicolumn{2}{c}{ biomass grouped by agricultural regions. } \\
\hline \multicolumn{1}{c}{ Region } & Potencial Production $(\mathrm{t})$ \\
\hline Área Metropolitana & $50,791.5$ \\
Campiña & $84,855.4$ \\
Guadarrama & 943.2 \\
Lozoya Somosierra & 13.480 .9 \\
Sur Occidental & $70,108.8$ \\
Vegas & $74,905.8$ \\
\hline
\end{tabular}

GiS Analysis for Bioelectricity Power Plants LOCATION IN THE MADRID COMMUNITY AGRICULTURAL REGIONS

Figure 2 shows the ideal locations for electricity generation power plants from biomass based on the criteria established in the methodology.

The municipality area around which a lower action radius is required to obtain the biomass necessary for the plant's supply has to be determined for each of the power plants.

The power needed in each of the plants is $2.2 \mathrm{MW}$, with an expected performance of $8,000 \mathrm{~h} / \mathrm{year}$, so the gross electricity production will be 17,600 MWh per year (net production will be somewhat lower due to auxiliary loads).

If the expected performance is less than $8,000 \mathrm{~h} / \mathrm{year}$, the gross electricity production will decrease and a lesser final biomass per year would probably be needed.

The plants will use solid biofuels from biomass produced by energy crops of rye and triticale, whose proportion will be determined in each case by their availability.

The amount of biomass required will depend on the lowest calorific power (LCP) upon arrival at the plant, which will be measured by its moisture content. The biomass should not be placed in the boiler at over 30\% moisture, although, for this work, only dry rye and triticale biomass is considered. Efficiency ranges from $21 \%$ to $22 \%$, so the intermediate value $(21.5 \%)$ has been used for the calculations.

\section{SUITABLE AREAS FOR THE LOCATION OF POWER BIOELECTRICITY PLANTS}

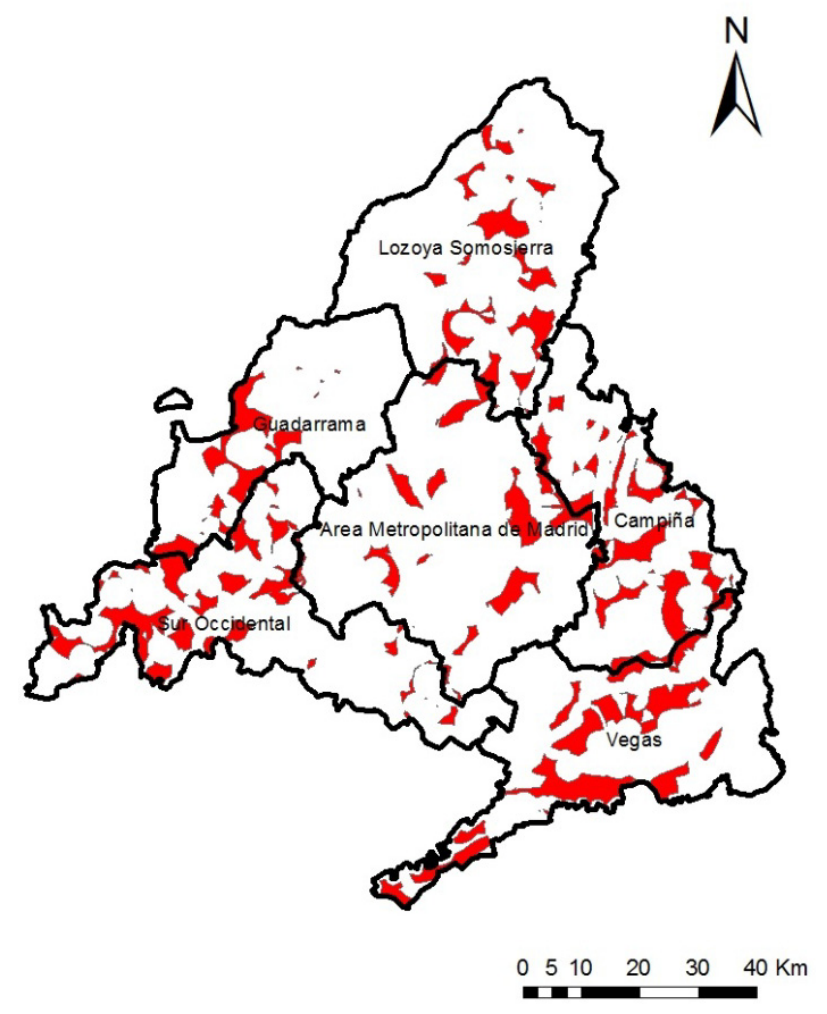

Figure 2. The suitable areas for the location of bioelectricity power plants in the Madrid Community agricultural regions are shown in red. 
As described above, the procedure for calculating the necessary biomass (M) is as follows (expressing $M$ in d.m. tons, $\mathrm{LCP}$ in $\mathrm{kcal} / \mathrm{kg}$ and $\mathrm{P}$ in $\mathrm{MWh})$ :

$$
\begin{gathered}
\mathrm{P}=\mathrm{LCP}^{*} \mathrm{M} * 0.215 / 860 \rightarrow \\
\mathrm{M}=17,600 * 860 / \mathrm{LCP}^{*} 0.215
\end{gathered}
$$

In the case of dry rye and triticale biomass, a $4,060 \mathrm{kcal} / \mathrm{kg}$ LPC is estimated (Fernández, 2008), so at least 17,339.9 tons are needed for each of the plants.

The minimum action radius for the biomass obtained will be calculated according to the established scenario ( $50 \%$ of the fallow dry land surface) in the six Madrid Community agricultural regions.

\section{Área Metropolitana Region}

The minimum action radius required to obtain the necessary biomass would be $10.2 \mathrm{~km}$ around the municipality of Getafe, and would include the municipality centroids of Alcorcon, Leganés, Pinto and Getafe itself (fig. 3). The potentially usable biomass on employing 50\% of the fallow dry land surface in the Área Metropolitana region would be distributed in the following manner:

- Alcorcón: 2,647.28 t

- Getafe: 6,029.75 t

- Leganés: 3,569.64 t

- Pinto: $6,851.78 \mathrm{t}$

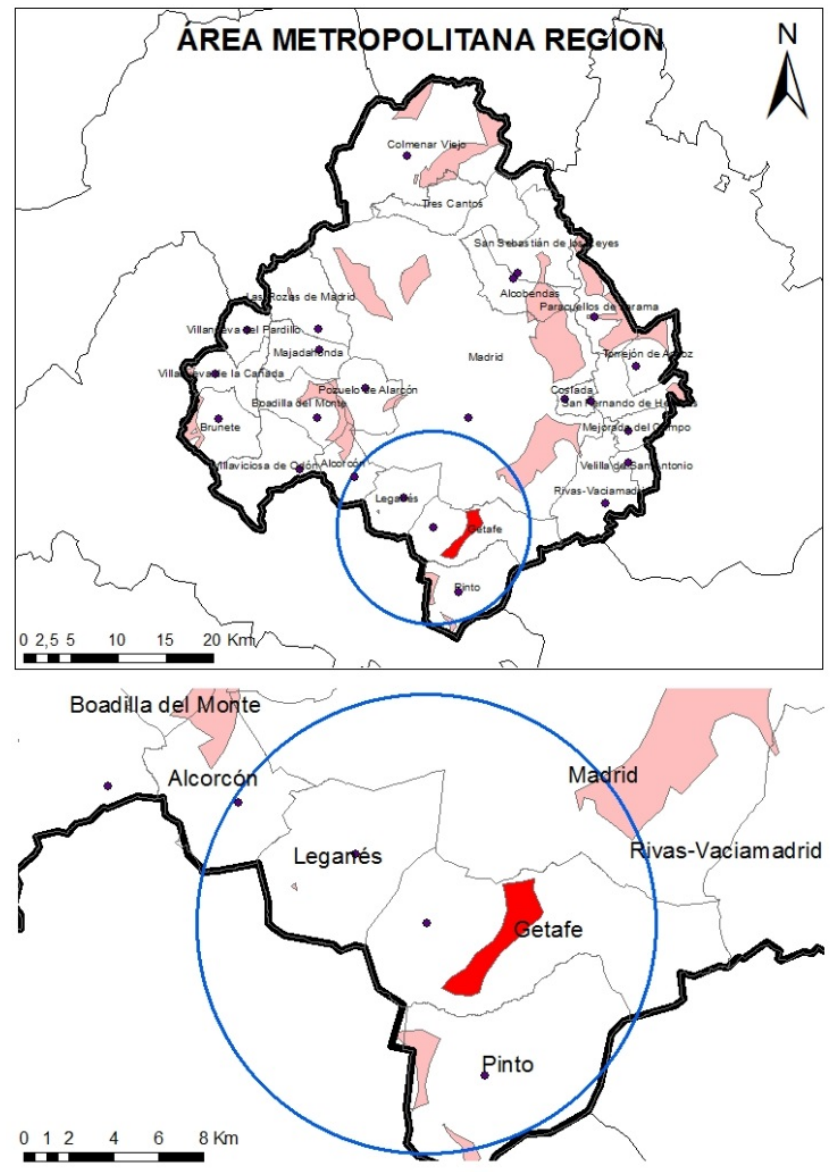

Figure 3. Minimum action radius to obtain the biomass required using $50 \%$ of fallow dry land surface and optimal area for the location of a 2.2 MW bioelectricity plant in Área Metropolitana region.
The total biomass that could be produced considering that action radius would be 19,098.45 $\mathrm{t}$.

\section{Campiña Region}

The minimum action radius required to obtain the necessary biomass would be $6.6 \mathrm{~km}$ around the municipality of Algete, and would include the municipality centroids of Cobeña, Daganzo de Arriba, Fuente el Saz de Jarama, Valdeolmos-Alalpardo and Algete itself (fig. 4). The potentially usable biomass using $50 \%$ of the fallow dry land surface in Campiña region would be distributed in the following manner:

- Algete: 3,937.50 t

- Cobeña: 2,694.93 t

- Daganzo de Arriba: 4,515.26 t

- Fuente el Saz de Jarama: 4,137.57 t

- Valdeolmos-Alalpardo: 3,145.41 t

The total biomass that could be produced considering that action radius would be $18,430.68 \mathrm{t}$.

\section{Guadarrama and Lozoya-Somosierra Regions}

The maximum potential that could be obtained using $50 \%$ of the fallow dry land surface for Guadarrama and Lozoya-Somosierra regions would be 943.20 and $13,480.94 \mathrm{t}$, respectively, an insufficient amount in both cases to satisfy the bioelectricity plant's needs, so that their location in this region is not considered.

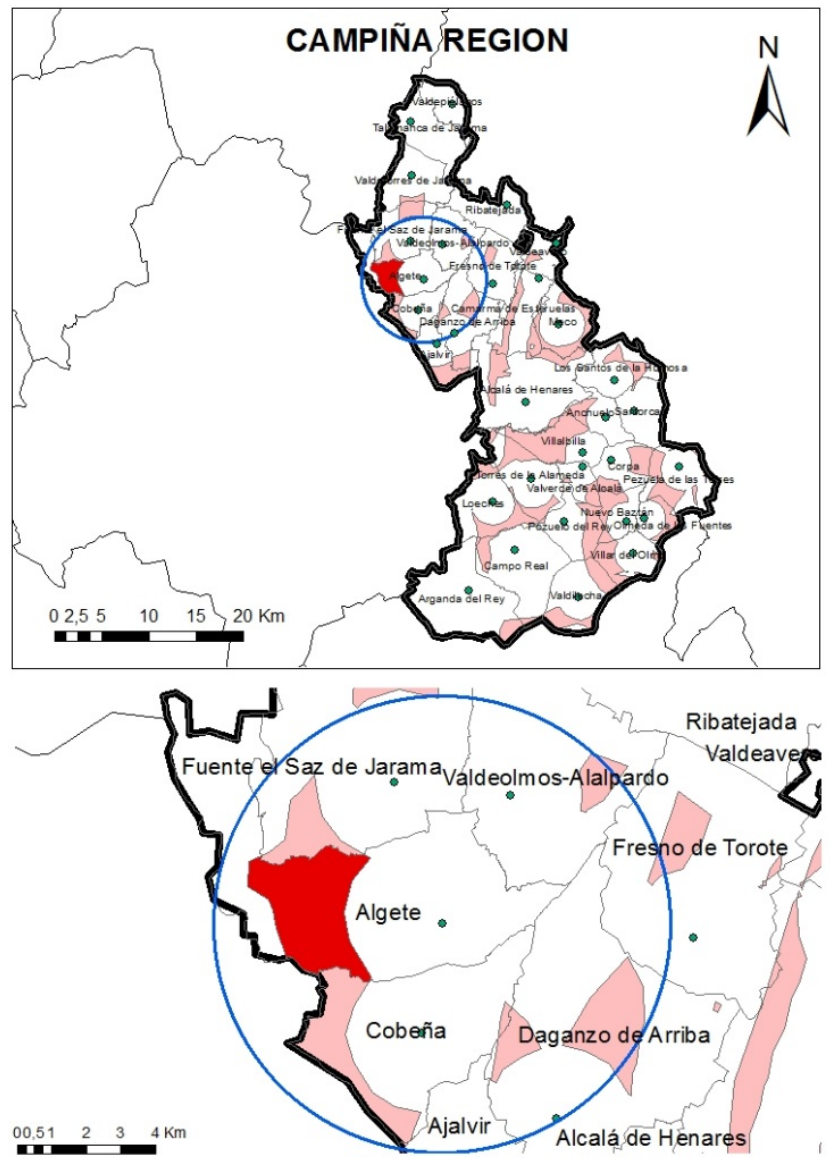

Figure 4. Minimum action radius to obtain the biomass required using $50 \%$ of fallow dry land surface and optimal area for the location of a 2.2 MW bioelectricity plant in Campiña region. 
However, the possibility of using biomass from forest pruning and woody crops could be contemplated because of the extensive surface devoted to these purposes in both regions.

\section{Sur Occidental Region}

The minimum action radius required to obtain the necessary biomass would be $6.5 \mathrm{~km}$ around the municipality of Torrejón de la Calzada, and would include the municipality centroids of Casarrubuelos, Cubas de la Sagra, Griñón, Humanes de Madrid, Parla, Torrejón de Velasco, and Torrejón de la Calzada itself, as illustrated in figure 5. The potentially usable biomass in $50 \%$ of the fallow dry land surface in Sur Occidental region would be distributed in the following manner:

- Casarrubuelos: $769.69 \mathrm{t}$

- Cubas de la Sagra: 2,115.82 t

- Griñón: $1,969.77 \mathrm{t}$

- Humanes de Madrid: 2,365.07 t

- Parla: 2,547.46 t

- Torrejón de la Calzada: $1,081.40 \mathrm{t}$

- Torrejón de Velasco: 6,834.24 t

The total biomass that could be produced considering that action radius would be $17,683.46 \mathrm{t}$.
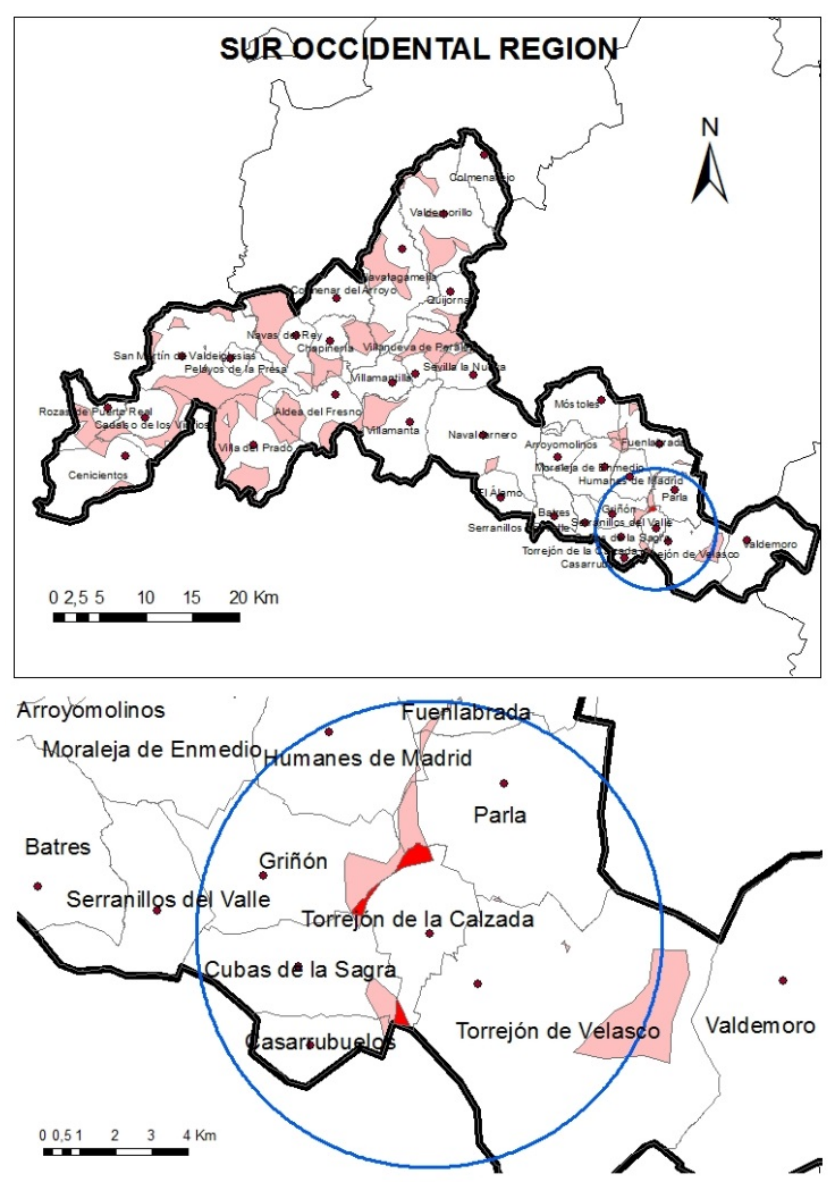

Figure 5. Minimum action radius to obtain the biomass required using $50 \%$ of fallow dry land surface and optimal area for the location of a 2.2 MW bioelectricity plant in Sur Occidental region.
Vegas Region

The minimum action radius required to obtain the necessary biomass would be $7.2 \mathrm{~km}$ around the municipality of Belmonte de Tajo, and would include the municipality centroids of Chinchón, Colmenar de Oreja, Valdelaguna, Villarejo de Salvanés, and Belmonte de Tajo itself, as illustrated in figure 6 . The potentially usable biomass in $50 \%$ of the fallow dry land surface in Vegas region would be distributed in the following manner:

- Belmonte de Tajo: 1,469.31 t

- Chinchón: 5,719.28 t

- Colmenar de Oreja: 5,940.86 t

- Valdelaguna: $1,416.51 \mathrm{t}$

- Villarejo de Salvanés: 6,162.04 t

The total biomass that could be produced considering that action radius would be $20,708 \mathrm{t}$.

\section{Bioflectricity Potential Production in the MADRID COMMUNITY AgRICULTURAL REgIONS}

As previously mentioned, at least $17,339.9 \mathrm{t}$ of rye or triticale biomass with an LCP of $4,060 \mathrm{kcal} / \mathrm{kg}$ would be required to satisfy the needs of a $2.2 \mathrm{MW}$ bioelectricity plant. However, the full bioelectricity potential that could be generated in the Área Metropolitana, Campiña, Sur Occidental and Vegas regions is quite superior.
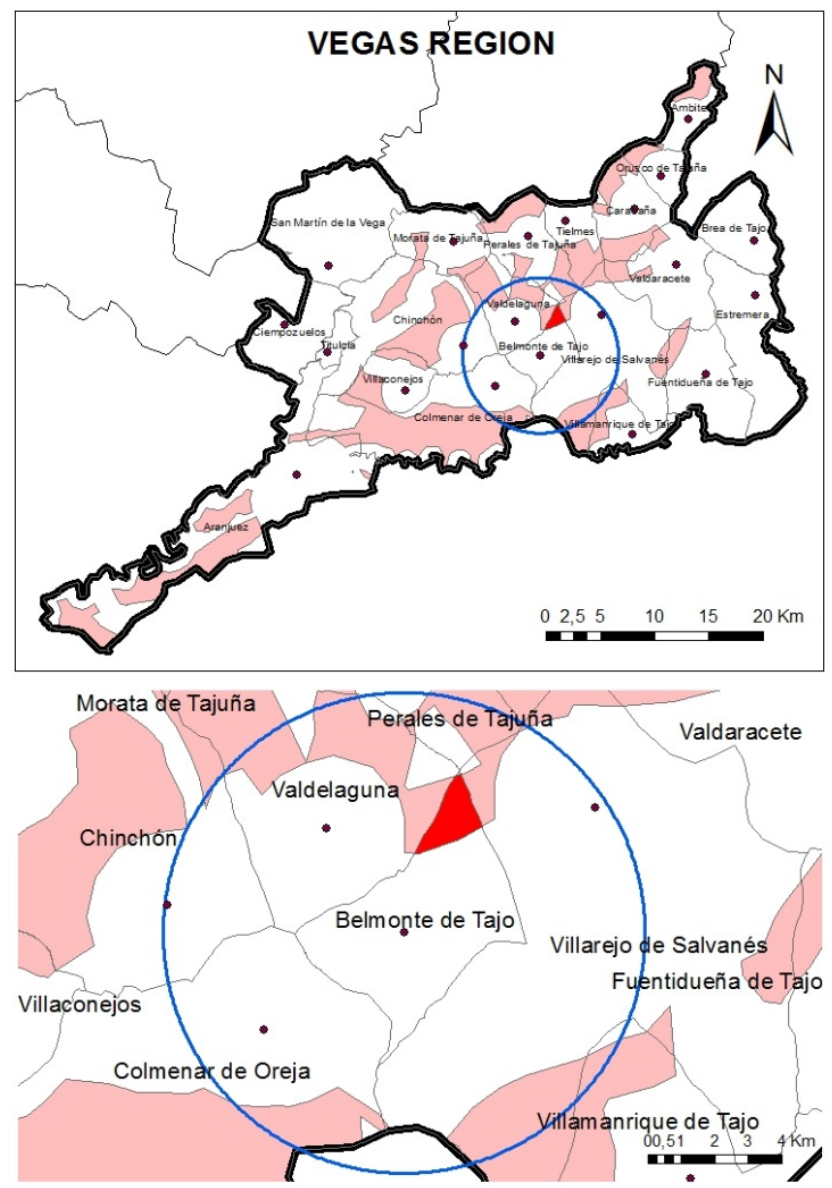

Figure 6. Minimum action radius to obtain the biomass required using $50 \%$ of fallow dry land surface and optimal area for the location of a 2.2 MW bioelectricity plant in Vegas region. 
The calculation procedure is the same used to determine the minimum needs of a $2.2 \mathrm{MW}$ electricity generation plant from biomass:

$$
\begin{gathered}
\text { Bioelectricity Potential }(\mathrm{MWh})= \\
\mathrm{LCP}^{*} \mathrm{M} * 0.215 / 860,
\end{gathered}
$$

where LCP is the lowest calorific power ( $\mathrm{kcal} / \mathrm{kg})$ and $\mathrm{M}$ is the necessary biomass (d.m. tons). Furthermore, a $21.5 \%$ efficiency and expected performance of $8,000 \mathrm{~h} /$ year is predicted.

The maximum bioelectricity potential that could be obtained using $50 \%$ of the fallow dry land surface in Área Metropolitana, Campiña, Sur Occidental and Vegas regions would be $6.44,10.77,8.90$, and $9.50 \mathrm{MW}$, respectively.

\section{CONCLUSIONS}

In the Madrid Community, the biomass used for electricity generation is derived exclusively from waste collected from gardens and agroforestry pruning as well as forestry and agricultural exploitation. There is a great biomass potential in the available agricultural area in the Community (mainly in the Southern regions).

The rye and triticale biomass production models elaborated in this work successfully reflect the yields obtained in the tests carried out in different areas of the Madrid Community.

At least 17,339.9 d.m. tons of rye and triticale (considering efficiency of $21.5 \%$, expected performance of $8,000 \mathrm{~h} /$ year, and a biomass LCP for both crops of 4,060 $\mathrm{kcal} / \mathrm{kg}$ ), and an average of 2,577 ha would be needed (which represents $2.79 \%$ of the fallow dry land surface in the Madrid Community) to satisfy the biomass needs of a 2.2 MW plant. By determining the most convenient location of these plants, we can conclude the following:

- Área Metropolitana region: municipality of Getafe and action radius of $10.2 \mathrm{~km}(19,098 \mathrm{t})$

- Campiña region: municipality of Algete and action radius of $6.6 \mathrm{~km}(18,431 \mathrm{t})$

- Guadarrama and Lozoya-Somosierra regions: the necessary biomass is not available

- Sur Occidental region: municipality of Torrejón de la Calzada and action radius of $6.5 \mathrm{~km}(17,683 \mathrm{t})$

- Vegas region: municipality of Belmonte de Tajo and action radius of $7.2 \mathrm{~km}(20,708 \mathrm{t})$

If a larger power plant had been chosen, the action radius would increase considerably in Campiña, Sur Occidental, and Vegas regions, and there would not be enough biomass in Área Metropolitana region to satisfy the plant's needs. This would lead to logistical problems and also a fee reduction per $\mathrm{kWh}$ produced.

The maximum bioelectricity potential that could be obtained in the Área Metropolitana, Campiña, Sur Occidental, and Vegas regions would be 6.44, 10.77, 8.90, and 9.50 MW, respectively.

\section{ACKNOWLEDGMENTS}

I would like to thank to the Project '2014 - ICF06' of the Industrial Engineering School of UNED and the Agroenergy Group of UPM for the support that they provided to prepare this work.

\section{REFERENCES}

Álvarez, M. (2004). Últimos avances en Sistemas de Información Geográfica. Ciclo de videoconferencias del Gabinete de Teleeducación, UPM.

Beccali, M., Columba, P., D’Alberti, V., \& Franzitta, V. (2009). Assessment of bioenergy potential in Sicily: A GIS-based support methodology. Biomass \& Bioenergy, 33(1), 79-87. http://dx.doi.org/10.1016/j.biombioe.2008.04.019.

CIEMAT. (2011). Proyecto Singular y Estratégico para el desarrollo, demostración y evaluación de la viabilidad de la producción de energía en España partir de biomasa de cultivos energéticos. PSE OnCultivos.

Fernandes, U., \& Costa, M. (2010). Potential of biomass residues for energy production and utilization in a region of Portugal. Biomass \& Bioenergy, 34(5), 661-666. http://dx.doi.org/10.1016/j.biombioe.2010.01.009.

Fernández, J. (2001). Producción de electricidad con biocombustibles sólidos, líquidos y gaseosos. La producción de electricidad con energías renovables y pilas de combustible: Curso de Invierno de la Universidad Complutense de Madrid.

Fernández, J. (2008). Energía de la biomasa. Energías Renovables para todos. Iberdrola.

Fiorese, G., \& Guariso, G. (2010). A GIS-based approach to evaluate biomass potential from energy crops at regional scale. Environ. Modelling \& Software, 25(6), 702-711. http://dx.doi.org/10.1016/j.envsoft.2009.11.008.

Hidalgo, F. (2003). Análisis multicriterio para la óptima ubicación de una central de energía a partir de biomasa en Andalucía. Sevilla: Universidad Pablo de Olavide.

IDAE (Instituto para la Diversificación y Ahorro de la Energía). (2007). Biomasa: Cultivos energéticos.

IDAE (Instituto para la Diversificación y Ahorro de la Energía). (2011). Plan de energías renovables 2011-2020.

Lovett, A., Sünnenberg, G. M., Richter, G. M., Dailey, A. G., Riche, A. B., \& Karp, A. (2009). Land use implications of increased biomass production identified by GIS-based suitability and yield mapping for Miscanthus in England. BioEnergy Res., 2(1-2), 17-28. http://dx.doi.org/10.1007/s12155-008-9030-x.

Martínez, S. (2009). Evaluación de la biomasa como recurso energético renovable en Cataluña. PhD thesis. Univ. de Gerona.

Montgomery, D. C., Peck, E. A., \& Vining, G. G. (2012). Introduction to Linear Regression Analysis (5th ed.). Hoboken, N. J.: Wiley Series in Probability and Statistics.

Perpiñá, C., Alfonso, D., Pérez-Navarro, A., Peñalvo, E., Vargas, C., \& Cárdenas, R. (2009). Methodology based on geographic information systems for biomass logistics and transport optimization. Renewable Energy, 34(3), 555-565. http://dx.doi.org/10.1016/j.renene.2008.05.047.

Rocha, A., Bert, F. E., Skansi, M. M., Veiga, H., Podesta, G. P., Ruíz, F., \& González, M. (2012). Pronóstico de rendimiento de los cultivos de granos en la región pampeana a través del uso de modelos de simulación agronómica. Modelo de simulación Ceres. Buenos Aires, Argentina: UBA.

Solano, M. L., Manzanedo, E., Concheso, R., Curt, M. D., Sanz, M., \& Fernandez, J. (2010). Potassium fertilisation and the termal behaviour of Cynara cardunculus L. Biomass \& Bioenergy, 34(10), 1487-1494. http://dx.doi.org/10.1016/j.biombioe.2010.04.025. 
Voivontas, D., Assimacopoulos, D., \& Koukios, E. G. (2001).

Assessment of biomass potential for power production: a GIS

based method. Biomass \& Bioenergy, 20(2), 101-112.

http://dx.doi.org/10.1016/S0961-9534(00)00070-2. 